\title{
Analisis faktor-faktor yang mempengaruhi impor kedelai di Indonesia
}

\author{
Nadya Grace*; Rahma Nurjannah; Candra Mustika \\ Prodi Ekonomi Pembangunan, Fak Ekonomi dan Bisnis,Universitas Jambi \\ *E-mail korespondensi:nadyagrace0897@gmail.com
}

\begin{abstract}
The purpose of the study was to find out how significant the contribution of soybean imports to the total imports of the food crop subsector and the effect of production, harvested area, exchange rate, and consumption on Indonesian soybean imports. The data used in this study is secondary data in the form of time series data for the period 2000-2016 derived from surveys that have been processed by the Central Statistics Agency of Jambi Province. The analytical method used is a descriptive and quantitative analysis using multiple linear regression analysis. The results showed that the contribution of soybean imports to the total imports of the food crop sub-sector in Indonesia experienced an increase, which fluctuated every year with an average of 24.87 percent. Based on the results of multiple linear analyses, it can be concluded that the factors that influence soybean imports in Indonesia are jointly controlled by the variables of soybean production, harvested area, exchange rate, and Indonesian soybean consumption. Meanwhile, simultaneously and partially, the soybean production and consumption variables have a positive and significant effect on Indonesian soybean imports. In contrast, the harvested area variable had a negative and significant impact, and the exchange rate had a negative and insignificant impact on Indonesian soybean imports.
\end{abstract}

Keywords: Contribution, Import, Production, Harvest area, Exchange rate,

\begin{abstract}
Abstrak
Tujuan penelitian adalah untuk mengetahui berapa besar kontribusi impor kedelai terhadap total impor subsektor tanaman pangan dan pengaruh produksi, luas panen, nilai tukar dan konsumsi terhadap impor kedelai Indonesia. Data yang digunakan dalam penelitian ini adalah data sekunder berupa data time series kurun waktu 2000-2016 yang berasal dari survei yang telah diproses oleh Badan Pusat Statistik Provinsi Jambi. Metode analisis yang digunakan adalah analisis deskriptif dan kuantitatif dengan menggunakan alat analisis regresi linear berganda. Hasil penelitian menunjukkan Kontribusi impor kedelai terhadap total impor subsektor tanaman pangan di Indonesia mengalami peningkatan yang fluktuasi tiap tahunnya dengan rata-rata sebesar 24,87 persen. Berdasarkan hasil analisis linear berganda diperoleh kesimpulan bahwa faktor yang mempengaruhi impor kedelai di Indonesia secara bersama-sama dipengaruhi oleh variabel produksi kedelai, luas panen, nilai tukar dan konsumsi kedelai Indonesia. Sedangkan secara simultan dan parsial variabel produksi dan konsumsi kedelai yang ternyata memiliki pengaruh positif dan signifikan terhadap impor kedelai Indonesia, sementara variabel luas panen berpengaruh negatif dan signifikan,nilai tukar berpengaruh negatif dan tidak signifikan terhadap impor kedelai Indonesia.
\end{abstract}

Kata kunci: Kontribusi, Impor, Produksi, luas panen, nilai tukar 


\section{PENDAHULUAN}

Indonesia merupakan negara yang menganut sistem perekonomian terbuka sehingga sangat mengandalkan kegiatan perdagangan internasional. Perdagangan Internasional adalah kegiatan untuk memperdagangkan berbagai output berupa barang dan jasa yang dihasilkan oleh suatu negara untuk dapat dijual ke luar negeri serta mendatangkan barang dan jasa dari luar negeri untuk kemudian didatangkan ke negara tersebut dengan tujuan memenuhi kebutuhan dalam negeri (Pambudi, 2011).

Perdagangan global merupakan aspek penting dalam perekonomian setiap negara. Tujuan dari perdagangan global adalah untuk meningkatkan kesejahteraan masyarakat disuatu negara. Hubungan yang saling mempengaruhi antar negara satu dengan negara lainnya dapat tercipta karena adanya perekonomian dalam negeri dan luar negeri, salah satunya adalah berupa pertukaran barang dan jasa antar negara. Tidak adanya batasan wilayah perdagangan di dunia dapat memperluas pangsa pasar ke negara lain (Iswandari, 2018).

Indonesia pada saat ini termasuk negara produsen kedelai keenam terbesar di dunia setelah Amerika Serikat, Brasil, Argentina, Cina, dan India. Namun, produksi kedelai domestik belum mampu mencukupi kebutuhan dalam negeri yang terus meningkat dari waktu ke waktu jauh melampaui peningkatan produksi domestik. Untuk mencukupinya, pemerintah melakukan impor. Pertumbuhan ekonomi di negara-negara berkembang yang membawa dampak kepada peningkatan kemakmuran akan terus berlanjut (Sari, 2015).

Sumber protein yang biasa dikonsumsi oleh masyarakat Indonesia yaitu kedelai, kedelai pada umumnya diproses dalam bentuk tempe dan tahu selain itu juga kedelai dapat dibuat menjadi kecap, susu kedelai dan juga menjadi tauco. Indonesia merupakan negara produsen tempe terbesar di dunia dan menjadi pasar kedelai terbesar di Asia.

Berdasarkan data SUSENAS tahun 2014 yang dirilis BPS, konsumsi tempe ratarata per orang per tahun di Indonesia sebesar 6,95 kg dan tahu 7,068 kg (Outlook Kedelai, 2016). Di Indonesia sampai saat ini masih terjadi kesenjangan yang sangat lebar antara produksi dan konsumsi kedelai (Sari, 2015). Peningkatan produksi kedelai tersebut belum dapat mencukupi ketersediaan kedelai. Sehingga untuk memenuhi kebutuhan kedelai tersebut, pemerintah melakukan kebijakan impor kedelai.

Kedelai merupakan komoditas strategis di Indonesia karena kedelai merupakan salah satu tanaman pangan penting di Indonesia setelah beras dan jagung. Komoditas ini mendapatkan perhatian yang lebih dari pemerintah dalam kebijakan pangan nasional. Selain sebagai sumber protein nabati, kedelai merupakan sumber lemak, mineral, dan vitamin serta dapat diolah menjadi berbagai makanan seperti tahu, tempe, tauco, kecap, dan susu (Zakaria, 2010).

Kebutuhan protein pada kedelai akan terus meningkat seiring dengan peningkatan jumlah penduduk dan pendapatan. Namun, dipihak lain penyedia sumber protein di Indonesia masih belum mencukupi. Pertumbuhan permintaan yang pesat baik untuk konsumsi manusia maupun untuk pakan ternak disatu sisi, sedangkan disisi lain pertumbuhan produksi kedelai dalam negeri belum mampu memenuhi pertumbuhan pemintaannya. Kesenjangan konsumsi dengan produksi semakin melebar, sehingga hal ini terpaksa di tutup dengan kedelai impor. Dalam upaya memacu peningkatan produksi kedelai untuk memenuhi permintaan dalam negeri dan substitusi impor yang meningkat, perlu dikaji sumber-sumber pertumbuhan produksi di berbagai provinsi di Indonesia (Aeni, 2014).

Impor kedelai pada tahun 2012 sebesar 1.211.230,0 US dollar dengan perkembangan 48,77\%, pada tahun 2013 mengalami penurunan nilai impor sebesar 
1.101.562,5 US dollar dengan perkembangan -40,57\%, pada tahun 2014 nilai impor kedelai sebesar 1.176.923,0 US dollar dengan perkembangan 6,84\%, namun pada tahun 2015 turun kembali sebesar 1.034.367,6 US dollar dengan perkembangan -12,11\%, dan pada tahun 2016 nilai impor sebesar 959.041,1 US dollar dengan perkembangan 7,28\% (BPS, 2016).

Produksi dan luas panen juga bisa mempengaruhi impor kedelai di Indonesia. Kita harus melihat bagaimana perkembangan Produksi dan luas panen kedelai di negara kita sendiri, karena jika produksi kita sedikit dan kebutuhan dalam negeri tidak tercukupi kemungkinan besar Indonesia banyak melakukan kegiatan impor. Akan tetapi setelah tahun 2000 produksi kedelai dapat dikatakan terus mengalami penurunan dan nilainya selalu berada dibawah 1 juta ton. Produksi mengalami penurunan pada tahun 2001 sedangkan konsumsi mengalami peningkatan yang telah menyebabkan terjadinya peningkatan impor. Setelah tahun 2000, produksi kedelai terus mengalami penurunan yang mengakibatkan hingga tahun ke tahun produksi tidak meningkat di atas 1 juta ton kembali dan telah mengakibatkan nilai impor dari tahun ke tahun mengalami peningkatan yang signifikan.

Dalam konsep jika luas panen kedelai di Indonesia kecil bisa mengakibatkan volume impor kedelai makin meningkat. Walaupun negara kita memilki luas lahan yang besar tetapi tidak ada yang menjamin bahwa setiap hektarnya produksi kedelai itu sama. Maka Indonesia harus memperhatikan perkembangan produksi kedelai, luas panen, nilai tukar Rupiah per Dollar, dan juga konsumsi kedelai di Indonesia.

Pengembangan komoditas kedelai untuk menjadi komoditas unggulan subsektor tanaman pangan perlu mendapat dukungan dari semua pihak yang terkait. Apabila telah mendapatkan dukungan dari semua pihak dapat dipastikan produksi kedelai meningkat sehingga dapat memenuhi kebutuhan masyarakat akan kedelai dan dapat menjadi swasembada pangan. Ketahanan pangan yang baik dapat menurunkan ketergantungan impor kedelai Indonesia terhadap negara lain.

Berdasarkan latar belakang maka penulis tertarik untuk melakukan penelitiantentang "Analisis Faktor-Faktor Yang Mempengaruhi Nilai Impor Kedelai Di Indonesia".

\section{METODE}

Jenis data yang digunakan dalam penelitian ini adalah Data Sekunder,berupa data time series kurun waktu 2000-2016 yang berasal dari survei yang telah diproses oleh Badan Pusat Statistik Provinsi Jambi.Data penelitian bersumber dari Badan Pusat Statistik Indonesia, Bank Indnesia Cabang Jambi, Basis data Statistik Pertanian, Referensi Jurnal, Makalah, dan lain sebagainya. Metode analisis yang digunakan yaitu analisis deskriptif dan regresi linear berganda.Menganalisis faktor-faktor yang mempengaruhi impor kedelai di Indonesia, digunakan model regresi dengan persamaan sebagai berikut :

$$
\mathrm{NM}_{\mathrm{i}}=\beta_{\mathrm{o}}+\beta_{1} \text { PROD }_{\mathrm{i}}+\beta_{2} \mathrm{LP}_{\mathrm{i}}+\beta_{3} \mathrm{KURS}_{\mathrm{i}}+\boldsymbol{\beta}_{4} \mathrm{Cons}_{\mathrm{i}}+\mathrm{e}_{\mathrm{i}}
$$

Dimana:

$\mathrm{NM}_{\mathrm{i}} \quad=$ Nilai impor

$\beta_{0} \quad=$ Konstanta

$\beta_{1}, \beta_{2}, \beta_{3}=$ Koefisien regresi

$\mathrm{PROD}_{\mathrm{i}} \quad=$ Produksi Kedelai (Ton)

$\mathrm{LP}_{\mathrm{i}} \quad=$ Luas panen Kedelai $(\mathrm{Ha})$

KURS $_{\mathrm{i}} \quad=$ Nilai tukar (rupiah)

Cons $_{\mathrm{i}}=$ Konsumsi kedelai Indonesia (Ton)

ei $\quad=$ Kesalahan pengganggu 


\section{HASIL DAN PEMBAHASAN}

\section{Kontribusi impor kedelai terhadap total impor subsektor tanaman pangan}

Berdasarkan Tabel 1 bahwa kontribusi total impor kedelai cenderung berfluktuasi dari tahun ke tahun, hal tersebut disebabkan sektor pertanian yang terdiri dari tanaman pangan impor komoditinya terus meningkat. Pada sektor pertanian Indonesia memiliki beberapa komoditi impor salah satunya adalah kedelai. Subsektor tanaman pangan merupakan bagian dari sektor pertanian memiliki peranan yang sangat penting dalam ketahanan nasional dan sebagai pemasok kebutuhan konsumsi penduduk, khusus Indonesia tanaman pangan juga berkedudukan strategis dalam memelihara stabilitas ekonomi nasional.

Tabel 1. Kontribusi impor kedelai terhadap total impor subsektor tanaman pangan

\begin{tabular}{cccc}
\hline Tahun & $\begin{array}{c}\text { Impor kedelai } \\
\text { (juta US) }\end{array}$ & $\begin{array}{c}\text { Impor subsektor tanaman } \\
\text { pangan (juta US) }\end{array}$ & Kontribusi \% \\
\hline 2000 & $557.148,0$ & $1.453 .031,0$ & 38,34 \\
2001 & $494.232,0$ & $1.459 .047,0$ & 33,87 \\
2002 & $582.475,0$ & $1.922 .286,0$ & 30,30 \\
2003 & $706.753,13$ & $2.034 .620,0$ & 34,73 \\
2004 & $967.957,30$ & $2.423 .418,0$ & 39,94 \\
2005 & $801.778,85$ & $2.115 .140,0$ & 37,90 \\
2006 & $809.056,65$ & $2.568 .453,0$ & 31,50 \\
2007 & $500.879,24$ & $2.729 .147,0$ & 18,35 \\
2008 & $732.722,93$ & $3.526 .961,0$ & 20,77 \\
2009 & $621.281,91$ & $2.737 .862,0$ & 22,69 \\
2010 & $840.037,0$ & $3.893 .840,0$ & 21,57 \\
2011 & $1.245 .963,0$ & $7.023 .936,0$ & 17,73 \\
2012 & $1.211 .230,0$ & $7.786 .315,0$ & 15,55 \\
2013 & $1.101 .562,5$ & $7.519 .027,0$ & 14,65 \\
2014 & $1.176 .923,0$ & $7.811 .894,0$ & 15,06 \\
2015 & $1.034 .367,6$ & $6.789 .739,0$ & 15,23 \\
2016 & $959.041,1$ & $6.498 .553,0$ & 14,76 \\
\hline
\end{tabular}

Sumber: Statistik Indonesia, 2016(diolah)

Kontribusi impor kedelai terhadap total impor subsektor tanaman pangan di Indonesia dari tahun 2000 sampai dengan 2016 rata-rata sebesar 24,87 persen. Kontribusi tertinggi impor kedelai terhadap total impor subsektor tanaman pangan terjadi pada tahun 2004 yaitu dengan nilai impor kedelai sebesar 967.957,30 atau sebesar 39,94\%.Untuk kontribusi tertinggi kedua terjadi tahun 2000 yaitu dengan nilai impor kedelai sebesar 557.148,0 atau sebesar 38,34\%. Dan kontribusi tertinggi ketiga terjadi tahun 2005 yaitu dengan nilai impor kedelai sebesar 801.778,85 atau sebesar 37,90\%. Hingga pada tahun 2016 impor kedelai mampu memberikan kontribusi terhadap impor subsektor tanaman pangan sebesar $14,76 \%$ dengan nilai impor kedelai sebesar 959.041,1.

Kontribusi komoditi kedelai tersebut memang belum cukup tinggi jika di bandingkan dengan kontribusi komoditi lainnya yang mampu memberikan kontribusi 
cukup tinggi terhadap total nilai impor subsektor tanaman pangan. Hal ini dikarenakan di Indonesia sumber daya alam (SDA) melimpah mulai dari sektor pertanian yang subsektor tanaman pangan komoditinya beras, jagung, gula, kedelai, cabai merah dan bawang merah serta komoditi lainnya. Gambaran mengenai kontribusi ini menunjukkan bahwa kontribusi impor kedelai terhadap impor subsektor tanaman pangan masih bertahan meskipun komoditi lainnya memberikan kontribusi besar terhadap subsektor tanaman pangan.

\section{Analisis faktor-faktor yang mempengaruhi impor kedelai Indonesia}

\section{Analisis regresi}

Hasil perhitungan regresidalam penelitian ini dapat di lihat pada Tabel 7,dengan menggunakan regresi liniear berganda dengan tingkat signifikansi sebesar $\alpha=5 \%$ yaitusebagai berikut:

Tabel 2. Hasil regresi impor kedelai Indonesia

\begin{tabular}{ccccc}
\hline \multicolumn{1}{c}{ Variable } & Coefficent & Std. Error & t-Statistic & Prob. \\
\hline C & 660219.6 & 475013.1 & 1.389898 & 0.1898 \\
PROD & 2.755887 & 0.853036 & 3.230680 & 0.0072 \\
LP & -3.728264 & 1.127296 & -3.307264 & 0.0063 \\
KURS & -44.91439 & 33.19700 & -1.352966 & 0.2010 \\
CONS & 0.448897 & 0.173528 & 2.419169 & 0.0324 \\
\hline $\mathrm{R}^{2}$ & $=0.737512$ & $(-4.108112)$ & $(3.717461)$ & $(2.586886)$ \\
T-stat & $=(-1.000970)$ & $(0.0001)$ & $(0.0005)$ & $(0.0126)$ \\
t-prob & $=(0.3216)$ & & & \\
F-stat & $=8.429116$ & & & \\
F-prob & $=0.001774$ & & & \\
\hline
\end{tabular}

Sumber: Data diolah, 2018

Berdasarkan Tabel 2, maka dapat di peroleh persamaan regresi sebagai berikut:

$\mathrm{NM}_{\mathrm{i}}=660219.6+2.755887 \mathrm{PROD}_{\mathrm{i}}-3.728264 \mathrm{LP}_{\mathrm{i}}-44.91439 \mathrm{KURS}_{\mathrm{i}}+\mathbf{0 . 2 8 6 4 7 9} \mathrm{CONS}_{\mathrm{i}}$

Persamaan regresi linear tersebut dapat diinterpretasikan sebagai berikut:

Nilai Konstanta sebesar 660219.6 memberikan arti bahwa jika PROD (produksi kedelai), LP (luas panen), KURS (nilai tukar), CONS (konsumsi kedelai) diasumsikan = 0, makanilai impor kedelai Indonesia (NM) akan turun sebesar 660219.6 juta US dollar.

Variabel bebas PROD (produksi kedelai) mempunyai koefisien regresi sebesar 2.755887, memberikan arti bahwa produksi kedelai berpengaruh positifterhadapnilai impor kedelai Indonesia dan besar probabilita 0,0072 signifikan pada $\alpha=5 \%$. Hal ini menunjukkan bahwa setiap kenaikan 1 ton pertahun maka akan terjadi peningkatan nilai impor kedelai Indonesia sebesar 2.755887juta US dollar.

Variabel bebas LP (luas panen) mempunyai koefisien sebesar -3.728264, memberikan arti bahwa luas panen kedelai berpengaruh negatif terhadap nilai impor kedelai Indonesia danbesarprobabilita 0,0063signifikanpada $\alpha=5 \%$. Hal ini menunjukkan bahwa setiap kenaikan 1 hektar lahan maka akan menurunkan nilai impor kedelai Indonesia sebesar 3.728264 juta US dollar. 
Variabelbebas KURS (nilai tukar) mempunyai koefisien sebesar -44.91439, memberikan arti bahwa nilai tukar berpengaruh negatif terhadap nilai impor kedelai Indonesia dan besar probabilita 0.2010 tidak signifikan pada $\alpha=5 \%$. Hal ini menunjukkan bahwa setiap kenaikan 1 rupiah per dollar Amerika Serikat maka akan menurunkan nilai impor kedelai Indonesia sebesar 44.91439 juta US dollar.

Variabelbebas CONS (konsumsi) mempunyai koefisien sebesar 0.448897, memberikan arti bahwa konsumsi kedelai berpengaruh positif terhadap nilai impor kedelai Indonesia dan besar probabilita 0.0324 signifikanpada $\alpha=5 \%$. Hal ini menunjukkan bahwa setiap kenaikan 1 ton pertahun maka akan meningkatkan nilai impor kedelai Indonesia sebesar 0.448897juta US dollar.

\section{Pengujian asumsi klasik}

\section{Uji multikolinearitas}

Muktikolinearitas sebagai suatu keadaan dimana terjadi korelasi liniearitas yang "perfect" atau exact diantara sebagian atau semua variabel bebas dalam model regresi. Setelah hasil estimasi maka dapat dilakukan uji multikolinearitas yang dapat dilihat dari nilai varians inflation factor (VIF) sebagai berikut:

Tabel 8.Hasil regresi multikolineritas

\begin{tabular}{lccc}
\hline \multicolumn{1}{c}{ Variable } & $\begin{array}{c}\text { Coefficient } \\
\text { Variance }\end{array}$ & $\begin{array}{c}\text { Uncentered } \\
\text { VIF }\end{array}$ & $\begin{array}{c}\text { Centered } \\
\text { VIF }\end{array}$ \\
\hline C & $2.26 \mathrm{E}+11$ & 173.1040 & NA \\
PROD & 0.727671 & 384.4442 & 7.418927 \\
LP & 1.270795 & 365.7896 & 6.300317 \\
KURS & 1102.041 & 90.29775 & 2.054740 \\
CONS & 0.014023 & 55.28397 & 1.338956
\end{tabular}

Sumber : Data diolah, 2018

Tabel 3 menunjukkan bahwa hasil nilai VIF variabel produksi kedelai (PROD) sebesar 7.418927, luas panen (LP) sebesar 6.300317, nilai tukar (KURS) sebesar 2.054740 dan konsumsi kedelai (CONS) sebesar 1.338956terhadap impor kedelai Indonesia kurang dari 10, maka dapat dinyatakan tidak terjadi gejala multikolinearitas dalam penelitian.

\section{Uji heterokedastisitas}

Ujiheterokedastisitas digunakan untuk melihat ada atau tidaknya penyimpangan dari asumsi klasik. Jika terjadi heterokedastisitas maka penaksir OLS tetap tak bias dan konsisten, tetapi penaksir tadi tidak lagi efisien baik dalam sampel kecil maupun besar. Model heterokedastisitas dapat dilihat pada Tabel berikut:

Tabel 4.Hasil regresi heterokedastisitas

\begin{tabular}{lcll}
\hline \multicolumn{4}{c}{ Heteroskedasticity Test: Glejser } \\
\hline F-statistic & 1.245859 & Prob. F(4,12) & 0.3435 \\
Obs*R-squared & 4.988296 & Prob. Chi-Square(4) & 0.2885 \\
Scaled explained SS & 3.664536 & Prob. Chi-Square(4) & 0.4533 \\
\hline
\end{tabular}

Sumber : Data diolah, 2018 
Tabel 4 menunjukkan bahwa hasil probabilita Chi-Square lebih besar dari nilai $\alpha$ yang dipilih yaitu $0.2885>0,05$ dan tidak mengalami signifikan dalam model pengujian glejser ini berarti variabel produksi kedelai, luas panen, nilai tukar, dan konsumsi kedelai Indonesia terhadap nilai impor kedelai Indonesia tidak terdapat heterokedastisitas.

\section{Uji autokorelasi}

Uji autokorelasi dengan menggunakan metode Breusch-Godfey umum dikenal dengan uji Lagrange Multiplier (LM). Masalah autokorelasi biasanya muncul dalam data time series meskipun tidak menutup kemungkinan juga pada data cross section. Berikut ini model Heterokedastisitas dapat dilihat pada Tabel berikut:

Tabel 5. Hasil regresi autokorelasi

\begin{tabular}{lcll}
\hline \multicolumn{4}{c}{ Breusch-Godfrey Serial Correlation LM Test } \\
\hline F-statistic & 0.075006 & Prob. F(2,10) & 0.9283 \\
Obs*R-squared & 0.251251 & Prob. Chi-Square(2) & 0.8819 \\
\hline
\end{tabular}

Sumber : Data diolah, 2018

Pada Tabel 5 menunjukkan bahwa hasil nilai Probabilita Chi-Square lebih besar dari nilai $\alpha$ yang dipilih yaitu 0.8819> 0,05 dan tidak mengalami signifikan dalam model pengujian Breusch-Godfey Serial Correlation LM Test ini berarti variabel produksi kedelai, luas panen, nilai tukar dan konsumsi kedelai Indonesia terhadap nilai impor kedelai Indonesia tidak terdapat autokorelasi.

\section{Uji normalitas}

Hasil uji normalitas menunjukkan bahwa nilai Probabilita J-B hitung lebih besar dari nilai probabilitas $\alpha(0,05)$ dalam pendekatan Jorque-Berra test maka hipotesis yang menyatakan bahwa variabel penggangu adalah bersistribusi normal diterima.

\section{Pengujian hipotesis}

\section{Uji signifikasi secara simultan (Uji-F)}

Hasil penelitian diperoleh nilai $\mathrm{F}$ hitung sebesar 8.429116 dengan probabilita sebesar $(0.001774)$ atau lebih kecil nilai $\alpha=0,05(0.001774<0,05)$, artinya $\mathrm{H}_{0}$ ditolak dan $\mathrm{H}_{\mathrm{a}}$ diterima pada tingkat keyakinan 95\%. Jadi dapat disimpulkan bahwa variabel produksi kedelai, luas panen, nilai tukar dan konsumsi kedelai Indonesia terhadap nilai impor kedelai Indonesia berpengaruh secara bersama-sama.

\section{Uji signifikansi secara parsial (Uji-t)}

Uji t digunakan untuk mengetahui signifikan pengaruh variabel independen (yaitu produksi, luas panen, dan konsumsi kedelai) secara parsial (individu) terhadap variabel dependen (impor kedelai Indonesia) yaitu dengan cara melihat signifikan $\alpha=5 \%$. Apabila tingkat signifikan lebih kecil dari $\alpha=5 \%$.

Hasil penelitian menjelaskan bahwa pengujian koefisien regresi variabel PROD (produksi), dapat dilihat bahwa nilai t hitung sebesar 3.230680 dengan probabilita variabel PROD (produksi) sebesar 0.0072 atau lebih kecil dari nilai $\alpha=5 \%(0.0072<$ 0.05), maka $\mathrm{H}_{0}$ ditolak dan $\mathrm{H}_{1}$ diterima. Artinya dapat disimpulkan bahwa secara parsial variabel produksi memiliki pengaruh signifikan terhadap impor kedelai Indonesia. 
Koefisien regresi variabel LP (luas panen), dapat dilihat bahwa nilai t hitung sebesar -3.30726 dengan probabilita variabel LP (luas panen) sebesar 0.0063 atau lebih kecil dari nilai $\alpha=5 \%(0.0063<0.05)$, maka $\mathrm{H}_{0}$ ditolak dan $\mathrm{H}_{1}$ diterima. Artinya dapat disimpulkan bahwa secara parsial variabel luas panen memiliki pengaruh signifikan terhadap impor kedelai Indonesia.

Koefisien regresi variabel KURS (nilai tukar), dapat dilihat bahwa nilai t hitung sebesar -1.35297 dengan probabilita variabel KURS (nilai tukar) sebesar 0.2010 atau lebih besar dari nilai $\alpha=5 \%(0.2010>0.05)$, maka $\mathrm{H}_{0}$ diterima dan $\mathrm{H}_{1}$ ditolak. Artinya dapat disimpulkan bahwa secara parsial variabel nilai tukar memiliki pengaruh tidak signifikan terhadap impor kedelai Indonesia.

Koefisien regresi variabel CONS (konsumsi kedelai), dapat dilihat bahwa nilai t hitung sebesar 2.419169 dengan probabilita variabel CONS (konsumsi kedelai) sebesar 0.0324 atau lebih kecil dari nilai $\alpha=5 \%(0.0324<0.05)$, maka $\mathrm{H}_{0}$ ditolak dan $\mathrm{H}_{\mathrm{a}}$ diterima. Artinya dapat disimpulkan bahwa secara parsialvariabel konsumsi kedelai memiliki pengaruh signifikan terhadap impor kedelai Indonesia.

\section{Koefisien determinasi $\left(\mathbf{R}^{2}\right)$}

Hasil yang diperoleh angka R-Squared sebesar 0.737512 atau $73.75 \%$. Dari koefisien determinasi $\mathrm{R}^{2}$ yang diperoleh dinyatakan bahwa variabel produksi, luas panen, nilai tukar dan konsumsi kedelai terhadap impor kedelai Indonesia hanya berpengaruh sebesar $73.75 \%$, sementara sisanya $26,25 \%$ dipengaruhi oleh variabel lain yang tidak dimasukkan dalam model penelitian ini.

\section{Interpretasi Hasil}

Selama periode penelitian tahun 2000-2016 dapat djelaskan bahwa nilai impor kedelai Indonesia dipengaruhi oleh produksi kedelai, luas panen, dan konsumsi kedelai. Berikut ini interpretasi koefisien regresi variabel-variabel dalam model regresi linier berganda yaitu sebagai berikut :

Dari hasil regresi untuk produksi berpengaruh signifikan terhadap nilai impor kedelai Indonesia. Dengan koefisien regresi produksi kedelai sebesar 2.755887 yang berarti setiap kenaikan produksi kedelai sebesar 1 ton pertahun maka akan meningkatkan nilai impor kedelai Indonesia sebesar 2.755887 juta US\$ pertahun. Hal ini dikarenakan kenaikan produksi dalam negeri diikuti oleh kenaikan konsumsi masyarakat terhadap kedelai yang lebih besar sehingga Indonesia masih melakukan impor tiap tahunnya dengan rata-rata produksi sebesar 1,36 persen dan konsumsi ratarata sebesar 2,05 persen.

Dari hasil regresi untuk luas panen berpengaruh signifikan terhadap nilai impor kedelai Indonesia. Dengan koefisien regresi luas panen sebesar -3.728264 yang berarti jika luas panen kedelai meningkat sebesar 1 hektar, maka akan menurunkan nilai impor kedelai Indonesia sebesar 3.728264 juta US\$ pertahun. Hal ini dikarenakan perluasan lahan panen yang meningkat maka membuat posisi produksi dalam negeri meningkat maka semakin kecil kemungkinan Indonesia akan mengimpor kedelai dari luar negeri.

Dari hasil regresi untuk konsumsi kedelai berpengaruh signifikan terhadap impor kedelai Indonesia. Dengan koefisien regresi konsumsi kedelai Indonesia sebesar 0.286479 yang berarti setiap terjadi penambahan konsumsi kedelai Indonesia sebesar 1 ton per tahun, maka akan meningkatkan nilai impor kedelai Indonesia sebesar 0.286479 juta US\$ per tahun. Hal ini dikarenakan semakin tinggi konsumsi kedelai maka berpotensi semakin meningkatkan impor kedelai. 


\section{Implikasi kebijakan}

Faktor yang mempengaruhi impor kedelai Indonesia periode 2000-2016, variabel produksi kedelai, luas panen, dan konsumsi kedelai Indonesia berpengaruh signifikan terhadap impor kedelai Indonesia. Artinya adalah apabila produksi kedelai dalam negeri menurun maka impor kedelai dari luar negeri akan mengalami peningkatan, apabila luas panen kedelai dalam negeri juga mengalami penurunan dan mengakibatkan produksi yang kita dapat di dalam negeri juga akan mengalami penurunan dan mengakibatkan impor kedelai dari luar negeri akan mengalami peningkatan, apabila nilai tukar mengalami depresiasi, yaitu nilai mata uang dalam negeri mengalami apresiasi sedangkan nilai mata uang asing melemah, maka nilai tukar akan menyebabkan ekspor meningkat dan impor cenderung menurun, namun apabila permintaan terhadap mata uang asing mengalami apresiasi akibatnya rupiah bisa mengalami depresiasi. Dan untuk konsumsi kedelai yang artinya untuk menekan impor kedelai dan mengurangi ketergantungan terhadap impor kedelai, dapat mencari bahan baku alternatif lain untuk pembuatan tahu dan tempe, misalnya dari kacang koro dan kacang tunggak atau masyarakat dapat beralih mengkonsumsi komoditas lokal lainnya seperti jagung, singkong dan umbi-umbian.

Kebijakan pemerintah merupakan salah satu faktor terpenting didalam perekonomian suatu negara, dan dalam hal mengambil suatu kebijakan pemerintah yang bertindak sebagai kontrol melalui berbagai kebijakan. Dalam hal ini perlu adanya kemandirian dari industri-industri kecil atau usaha kecil dan menengah (UKM) yang menggunakan bahan baku kedelai untuk mampu memakai bahan baku kedelai dalam negeri dan tidak bergantung pada produk kedelai impor saja. Karena jika UKM mampu memakai produk kedelai dalam negeri dan UKM tersebut berkembang maka akan dapat mengurangi dan menekan angka volume atau nilai impor kedelai di Indonesia. Adanya jaminan harga yang stabil dan menarik bagi petani juga merupakan langkah strategis berikutnya dalam upaya meningkatkan produksi jagung dalam negeri.

Tingginya ketergantungan impor kedelai akibat konsumsi kedelai tinggi yang tidak diimbangi dengan penambahan produksi kedelai dalam negeri. Disatu sisi nilai tukar yang terus mengalami depresiasi akibat situasi perekonomian yang belum stabil menyebabkan perindustrian pengolahan bahan makanan dari kedelai seperti tahu dan tempe dalam negeri rentan terhadap kebangkrutan. Sehingga untuk tetap memenuhi permintaan tempe dan tahu pemilik industri tersebut menaikkan harga jualnya. Ini yang menyebabkan impor meningkat seiring dengan nilai tukar yang meningkat (Iswandari, 2018).

\section{KESIMPULAN DAN SARAN}

\section{Kesimpulan}

Kontribusi impor kedelai terhadap total impor subsektor tanaman pangan di Indonesia cenderung berfluktuasi dengan rata-rata sebesar 24,87 persen.Berdasarkan hasil analisis menggunakan regresi linear berganda untuk melihat faktor-faktor yang mempengaruhiimpor kedelai di Indonesia, maka diperoleh hasil sebagai berikut:

Berdasarkan hasil regresi variabel produksi dan konsumsi kedelai berpengaruh positif dan signifikan, variabel luas panen berpengaruh negatif dan signifikan terhadap impor kedelai. Sedangkan variabel nilai tukar tidak berpengaruh signifikan.

\section{Saran}

Sangat diperlukan kebijakan pemerintah dalam hal pengembangan pada subsektor tanamanpangan dengan baik sehingga Indonesia dapat menguasai pasar domestik dan pasar Internasional untuk menghasilkan output komoditas yang tinggi kuantitas dan kualitas.Diharapkan kepada pemerintah diperlukan usaha yang lebih maksimal dalam 
melakukan ekstensifikasi terhadap lahan kedelai agar produksi kedelai di Indonesia juga meningkat. Memberikan binaan dan sosialisasi kepada masyarakat agar memanfaatkan lahan yang kosong dan perkarangan untuk menanam kedelai sehingga produksi kedelai dapat meningkat dan diperlukan kebijakan kuat dari pemerintah dalam meningkatkan kualitas benih kedelai domestik dan jumlah produksi kedelai domestik, agar Indonesia tidak lagi bergantung kepada kedelai impor.

\section{DAFTAR PUSTAKA}

Aeni, Sabrina Febri. (2014). Pengaruh produksi kedelai dalam negeri dan kurs terhadap impor Kedelai Indonesia. Skripsi. Fakultas Ekonomi. Universitas Muhammadiyah Malang: Malang.

Badan Ketahanan Pangan Kementrian Pertanian.(2016). Data statistik ketahanan pangan Tahun 2015: Jakarta

Badan Pusat Statistik. (2016). Data produksi, luas panen, impor kedelai Indonesia. Impor. BPS: Jambi.

Bank Indonesia. (2016). BI rate. Diakses dalam di http://www.bi.go.id. Tanggal 20 September 2016. Pukul 10.00 WIB.

Iswandari, Diah Ayu. (2018). Analisis faktor-faktor yang mempengaruhi kedelai di Indonesia Tahun 1997-2015. Skripsi. Ekonomi Pembangunan Fakultas Ekonomi . Universitas Muhammadiyah Surakarta: Surakarta.

Noviantoro,B; E Emilia; \& YV Amzar. (2017).Pengaruh harga CPO, harga minyak mentah dunia, harga karet dunia dan kurs terhadap defisit neraca transaksi berjalan Indonesia, Jurnal Paradigma Ekonomika, 12 (1), 31-40

NR Sartika, A Amril, D Artis. (2018). Analisis determinan impor gula Indonesia dari Thailand, e-Jurnal Perdagangan Industri dan Moneter 6 (1), 1-13

Pambudi, Archibald Damar. 2011. Analisis Faktor-Faktor yang Mempengaruhi Ekspor Biji Kakao Indonesia ke Malaysia dan Singapura. Skripsi. Fakultas ekonomi. Universitas Diponegoro: Semarang

PUSDATIN. (2017). Outlook kedelai 2016. Depatemen Pertanian : Jakarta.

Sari, Putri Meliza. (2015). Analisis faktor-faktor yang mempengaruhi konsumsi kedelai di Indonesia. Journal of Economic and economic Education,4 (1), 30-41.

Statistik Pertanian. (2017). Kementrian pertanian. Pusat Data dan Sistem Informasi Pertanian : Jakarta.

Zakaria, Amar.K. (2010). Program pengembangan agribisnis kedelai dalam peningkatan produksi dan pendapatan petani. Avalible online at : www.depten.go.id Accessed 20 Des '15. Jurnal Litbang Pertanian, 4 (29), 67-68. 